\title{
The role of biotechnology in agricultural production and food supply
}

\author{
Araceli Cano Estrada1, Daniel Vélez Díaz ${ }^{1}$, Carlos Alberto Morgado \\ Hernández ${ }^{2}$ \\ 'Universidad Autónoma del Estado de Hidalgo, Escuela Superior de Tlahuelilpan. Av. Universidad s/n Ex \\ hacienda de San Servando. Col. Centro, Tlahuelilpan Hidalgo, México. \\ ${ }^{2}$ Universidad Autónoma del Estado de Hidalgo, Instituto de Ciencias Económico Administrativas. Campus \\ la Concepción Km 2.5. San Juan Tilcuautla. San Agustín Tlaxiaca. Hidalgo, México.
}

\begin{abstract}
A. Cano, D. Díaz and C. Morgado. 2017. The role of biotechnology in agricultural production and food supply. Cien. Inv. Agr.44(1): 1-11. Over the past several decades, technological developments and modernization have grown concomitantly.For example, advances in biotechnology have been used as a tool to increase food production. Specifically, advances in genetic engineering have made possible the manipulation of crops to increase yield, guaranteeing food supplies for the increasing world population. However, transgenic crops have not been well received by all members of society, and there is still uncertainty about their social benefits and the possible implications to human health. Additionally, the benefits of agricultural modernization have favored only developed countries, whereas people living in developing and underdeveloped countries suffer rampant hunger, malnutrition and poverty. Hence, there is a necessity to create policies guaranteeing that the advances in biotechnology are translated into better agricultural practices that can meet the ever-growing food demand. The agricultural modernization process, however, must consider that sustainable development is imperative in modern societies and that there is an increasing desire for consuming so-called organic foods based on the idea that these foods have a higher quality and stimulate regional agricultural production. This review discusses the role of biotechnology throughout history in relation to agricultural production and the development of the food sector.
\end{abstract}

Key words:Agriculture, development, food industry, nutrition, organic food, transgenic food.

\section{Introduction}

The increase in human population worldwide has become a major threat to food security. Population growth, particularly in countries with developing economies, will result in the need for a $70 \%$ increase

Received May 11, 2016.Accepted March 09, 2017. Corresponding author: edith_cano@uaeh.edu.mx in food production by the year 2050 (Delaney, 2015), making the significant enhancement of agricultural productivity in the next several decades a priority. In this respect, efforts of biotechnology have been concentrated on creating technologies that can increase crop yields.

Although biotechnology applications can be traced to $6000 \mathrm{BC}$, it was in the 1970 s when the 
development of genetic tools and cellular and tissue engineering gave the biotechnology field new momentum that allowed a range of possible novel applications (Awais et al., 2010).

The increasing recognition of biotechnology as an economic and social growth factor has stimulated governments in several countries to provide financial support to their local biotechnology companies to foster research, development, and commercialization of ideas and products (Awais et al., 2010); on the other hand, projections of malnutrition, famine, untreatable diseases and unresolved environmental problems have boosted biotechnological innovations and improvement in the quality and services provided by these companies (Boccia and Sarnachiaro, 2015; Dash et al., 2016). One remarkable example of biotechnology innovation is the production of genetically modified (GM) crops aimed at insect and weed control that result in increased crop yields (Dash et al., 2016).

Despite the great biotechnological advances in agricultural production achieved over the past 50 years, the efforts to mitigate poverty and inequality have proven to be insufficient, mostly in rural areas. Food safety is handled by different approaches in different regions and social strata (FAO, 2012), and in fully developed countries, there still are people suffering from starvation and illnesses linked to it. Considering the advances in technology, hunger has been translated into an avoidable harm that must not be forgotten.

In the past decade, consumer behavior concerning food products has been influenced by quality and safety (Boccia and Sarnachiaro, 2015). Currently, highly processed foods with a high content of chemical products are not accepted among the population, and there is a clear tendency towards consuming fresh food. Biotechnology has provided, via genetic manipulation of crops, a means to guarantee food production or crop nutritional improvement (Fernández-Suaréz, 2009). However, GM crops have become the center of debate due to the discrepancy of opinions that arise around the repercussions that the consumption of these types of food may have on human health. This review describes the biotechnological advances at different periods of history and how their efforts have concentrated on trying to mitigate the shortage of food supply and associated malnutrition. This review analyzes current trends towards healthier food consumption and its sustainable development. The goal of this review is to discuss the controversy around the application of these biotechnological tools for improving agricultural production.

\section{Biotechnological development of agriculture}

Agriculture has been the backbone of the human food supply directly and indirectly. However, agricultural land is limited, and it has decreased over time due to the increasing world population. Therefore, global agricultural productivity must increase in order to meet the increasing food demands (FAO, 2013). Agriculture is considered one of the oldest activities practiced by humankind. In the beginning, agriculture was manually practiced; later, primitive technologies based on the use of the plow and the harrow allowed an increase in agricultural productivity. The Industrial Revolution, which spanned from 1875 to 1885 , enabled an accelerated economic development that became strategic for the growth of countries (FAO, 2012), which in turn triggered the migration of people from rural areas to industrialized cities. To increase agricultural production and meet consumer and producer needs, the use of machinery on farms was imperative, progressing through remarkable improvements. The introduction of chemical fertilizers around the same period of time enabled crop protection against disease and attainment of higher yields. One of the first chemicals employed was nitrogen based, although its use was restricted due to high costs.

In England, agriculture became a science by performing novel experiments aimed at improving agricultural methods (Cubero, 1993), which 
eventually led to important innovations such as crop rotation and new discoveries such as the ability of some legumes to convert atmospheric nitrogen to nitrates (Overton, 1996).

One of the earliest records of plant hybrids was the report by Cotton Mather in 1716. The next important documentation regarding the development of plant hybridization was provided by quarter in 1776. Gregor Mendel's postulates related to how different traits were passed from one generation to the next, and his paper "Experiments on plant hybridization", published in 1866 (Persley, 1991), marked the beginning of new technologies designed to improve vegetable species. However, plant hybridization occurred long before Mendel's experiments; most likely it was unintentional at first and could have occurred at any stage in the crop domestication process (Vasey, 1992). In fact, crosses for both floral morphology and hybrid vigor were greatly expanded by many researchers during the next 100 year (Teranishi, 1978). In 1970, plants genetics allowed obtaining plant species that were more productive and exhibited resistance to some pests.

In 1960, a new movement changed farming: The Green Revolution, which is a term used for the rapid increase in food production, especially in underdeveloped and developing nations, via the introduction of high-yield crop varieties and the application of modern agricultural techniques (FAO, 2004). The Green Revolution arose as the technological response to a worldwide food shortage, which became threatening in the period after World War II. The technologies developed during this period, which usually involve bioengineered seed that worked in conjunction with chemical fertilizers and heavy irrigation, had a huge impact on three main cereals (maize, wheat and rice).

A particularly important finding was the discovery how the biological molecule of DNA was responsible for inheritance.In the 1960s, the genetic code was cracked, and subsequent studies began the transfer of genetic material from one organism to another by genetic engineering techniques (Dash et al., 2016). The intersection between genetic engineering and biotechnology was the main factor in the creation of genetically modified organisms(GMOs)(Table 1).

One of the first agricultural research centers was the International Maize and Wheat Improvement Center (CIMMYT), which was created in Mexico in the 1960s, with the help of the Rockefeller Foundation (FAO, 2000; Ceccon, 2008). At this institute, Mexicans and foreign researchers worked together for the genetic improvement of crops and produced exceptional results: in just two decades, wheat productivity increased from $750 \mathrm{~kg} \mathrm{ha}^{-1}$ in 1950 to $3200 \mathrm{~kg}$ ha $^{-1}$ in 1970 (Ceccon, 2008). Today, wheat and maize produced from research at CIMMYT are planted in millions of hectares around the word. However, one limitation regarding basic and ap-

Table 1. Summary of the main events in the development of biotechnology

\begin{tabular}{|c|c|}
\hline Period & Events \\
\hline 1664 & Discovery of microorganisms. \\
\hline 1884 & Discovery of bacteria. \\
\hline 1857 & Microbiology of lactic fermentation. \\
\hline 1860 & End of the spontaneous generation theory \\
\hline 1866 & Mendel's postulates of classical genetics. \\
\hline 1875 & Beginning of the use of machinery in farming \\
\hline 1941 & Onegene-one enzyme hypothesis \\
\hline 1946 & Bacterial conjugation. \\
\hline 1953 & DNA structure. \\
\hline 1959 & Gene regulation. \\
\hline 1960 & Green Revolution \\
\hline 1966 & Genetic code decoding \\
\hline 1970 & $\begin{array}{l}\text { High specificity of restriction enzymes. } \\
\text { Rise of phytogenetics } \\
\text { CIMMYT foundation }\end{array}$ \\
\hline 1973 & Recombinant DNA. \\
\hline 1978 & Human proinsulin gene isolation \\
\hline 1985 & Polymerasechainreaction. \\
\hline 1992 & Beginning of the Golden Rice project \\
\hline 1996 & Full-fledged commercialization of GM crops \\
\hline
\end{tabular}


plied agrarian research is that it usually is carried out in developed countries with specified climate conditions, and innovations and improvements in crop yield can only be obtained in similar conditions. For this reason, it was necessary to adapt the new technologies and discoveries to warmer or more arid climates that prevail in underdeveloped countries.

One of the first genetically engineered crops worldwide was soybean MON87701, produced under the brand name Itanca, which expressed the crystal insecticide protein CytAclderived from Bacillus thuringiensis (Bt toxin) that provided protection against feeding damage caused by some lepidopteran pests (EFSA, 2011). In addition, Monsanto introduced the GMO soybean MON89788, a crop expressing the cp4-epsps gene from the soil bacterium Agrobacterium tumefaciens, which encodes the EPSPS enzyme, providing resistance to the herbicide glyphosate. Monsanto subsequently engineered a stacked trait soybean using MON89788 x MON87701 (Then and Bauer-Panskus, 2017), combining into one GMO the expression of the insecticidal Bt toxin, CrylAc, with resistance to glyphosate. GM soybean has made rapid strides in recent decades, and its cultivation area has been increasing yearly. Currently, genetic modification has been successful in maize, tomato, rice and cotton plantations (Sanahuja et al., 2011; Tabashnik et al., 2011), mainly by inserting exogenous genes (transgene) that encode a protein that is toxic to specific pests.

It has been observed that some microorganisms, including plant growth-promoting bacteria, fungi and cyanobacteria, have shown biofertilizer-like activities in the agricultural sector (Mahanty et al., 2016). The utilization of microbes as biofertilizers is currently being considered, to some extent, as an alternative to chemical fertilizers to enhance crop production.

The use of nanotechnology can boost agricultural production, and it is becoming one of the most important tools in modern agriculture. Nano- technology provides new agrochemical agents and new delivery mechanisms to improve crop productivity, and it promises to reduce pesticide use through nanoformulations of agrochemicals. Nanotechnology also allows the application of nanosensors/nanobiosensors in crop protection (Bhupinder, 2014).

\section{Biotechnological development of food}

For years, biotechnology has been employed in the food sector through the production of additives and ingredients as well as the development of more efficient and less costly operations for the production of food. In addition, biotechnological interventions have been focused on modifying or enhancing taste, aroma, shelf-life, texture and nutritional value of food products, employing fermentation, enzyme technology, nanotechnology and molecular biology.

It was thought that technology would become a tool that would help solve the problems of the worldwide supply of food. However, this has not occurred. Nonetheless, it is convenient to note the great achievements that were carried out thanks to the discovery of microorganisms and the development of biological, biochemical and molecular techniques that allowed the progress of this branch of science (Table 1).

In 1857 and 1860, Luis Pasteur discovered the microbiology of lactic fermentation and the function of yeast in alcoholic fermentation. These types of fermentations continue to be the most popular process for obtaining food to date (Madigan, 2007). These processes can be carried out naturally, such as cocoa fermentation. It is likewise possible to employ inocula to obtain foods such as yogurt and cheese. Fermentation can occur in pre-established cultivation media as in the production of beer, in the production of primary metabolites (alcohol and organic acids) and in the production of secondary metabolites (enzymes and polysaccharides). 
Currently, fermentation is still a very useful technique for food processing. Fermented food from different sources such as milk, cereal, fruits, vegetables and meat have contributed a great deal to the livelihood of rural and urban people. The organisms involved in fermentation continue being objects of studies. One example is how lactic acid bacteria could fulfill the novel role of efficient cell factories for the production of functional biomolecules and food ingredients to enhance the quality of cereal-based beverages (Waters et al., 2015).

Enzymatic technology has been a tool used for food biotechnology because it has helped optimize and accelerate bioprocesses.In various food-processing sectors, such as baking, juice processing, starch, dairy and other related industries, enzyme play a crucial role as biocatalysts in the biotransformations process (Dash et al., 2016).

A large number of enzymes are used in the food industry. For example, in the bakery industry, proteases act on the protein of wheat flour, reducing the gluten elasticity and therefore reducing the shrinkage of dough.

In the dairy industry, rennet has been used since ancient times to help the clotting of milk in obtaining cheese. The use of lactase for the production of low-lactose milk is another important dairy application. The use of the enzymes such as cellulose and pectinases in the manufacture of fruit juice can give better juice yield with high quality. In addition, papain and bromelin are proteases used as meat softeners.

Conventional food processing techniques are well developed, but processing often leads to lowered nutritional value (Nakitto et al., 2015). Biofortification is the application of biotechnology to fortify with external supplementations, and biofortification has seen new approaches, such as injection of vitamin $\mathrm{D}$ into bread and milk to overcome deficiencies.

The birth of classical genetics was another milestone in the development of biotechnology with the experiments developed by Mendel.The production of nectarines, apples with pear flavor and other types of hybrids has occurred, and these products have been accepted by consumers.

In the middle of the twentieth, the development of biotechnology accelerated thanks to the scientific discoveries that gave rise to genetic engineering. GM foods are produced from GMOs. Typically, GM foods are transgenic plant products. A tomato, called FlavrSavr, was the first commercial GM food, which was modified to ripen without softening by the Californian company Calgene (Bagwan et al., 2010). It was welcomed by consumers who purchased the fruit at a substantial premium over the price of regular tomatoes. However, production problems and competition for a conventionally bred variety with a longer shelf life prevented the product from becoming profitable.

A cancer-fighting tomato with three times more lycopene (an antioxidant) than conventional varieties has been developed by Purdue University and the U.S. Department of Agriculture's Agricultural Research Service (Awais et al., 2010). Lycopene is known to trap harmful molecules that damage human body tissue and may lower the risk of breast and prostate cancers.

Genetic engineering also plays a significant role in enhancing protein, vitamin A and vitamin $\mathrm{E}$ as well as iron and zinc components by gene insertion. In 1992, the Golden Rice project started. Golden Rice is a variety of Oryza sativa designed to produce beta-carotene, a precursor of vitamin A, in the endosperm, which is the edible part of rice. It was created by Ingo Potrykus of the Institute of Plant Sciences at the Swiss Federal Institute of Technology, working together with Peter Bayer of the University of Freiburg (Bagwan et al., 2010). Golden Rice was developed as a fortified food to be used in areas where there is a shortage of dietary vitamin A. A new variety called Golden Rice 2 was announced in 2005. Golden Rice 2 produces up to 23 times more beta-carotene than the original version. 
Bt corn is a variant of GM maize that expresses the bacterial Bt toxin, which is poisonous to the European corn borer.However, there are several foods from GM crops that are resistant to herbicides (glyphosate) and/or resistant to insects (using Bt toxin), including crops such as soybean, canola, sweet corn and sugar beet (Bagwan et al., 2010).

However, despite the different biotechnological achievements, the consumption of transgenic food is still associated with a lack knowledge regarding their effects on the environment and human health. (Boccia and Sarnacchiaro, 2015).

\section{Transgenic food}

Transgenic foods, also known as genetically modified or engineered foods, are defined as those that are produced and/or are processed from organisms that have had changes introduced into their DNA using the methods of genetic engineering (Fernández-Suárez, 2009; Herrera-Díaz and Gómez-Solis, 2011; PALT, 2014).

Transgenic foods can include the following:

a) Crops that can be directly used as food and that have been genetically modified, e.g., corn crops that are pest resistant.

b) Food that contains an ingredient or an additive derived from a GMO.

c) Foods that uses an auxiliary product for their production derived from a GMO, e.g., cheese made from recombinant chymosin obtained from a strain of the fungus Aspergillus niger that has been genetically manipulated to produce the bovine enzyme.

Biotechnology has played an important role in the advancement of the health sector with great benefits to the human race.Biotechnology applications in health have taken advantage of the chemistry of living organisms for molecular biology or cell manipulation to develop new or alternative methods aimed at finding more effective ways of producing traditional products. One of the genetic engineering techniques that have been used for the treatment and prevention of diseases is the recombination of deoxyribonucleic acid (rDNA); this technique artificially joins pieces of deoxyribonucleic acid from different organisms, e.g.,recombinant insulin, which was produced by cloning the human insulin gene into a DNA plasmid that was transformed and expressed into the bacterium Escherichia coli. The use of this technique has allowed the production of insulin at an industrial scale, which is now commercialized at very competitive prices and contains characteristics similar to those of the human hormone for use by diabetic patients. Even though in this particular casethe use of genetic engineering has gained wide acceptance among society, when we discuss transgenic food, which can also be beneficial to human health, or agricultural biotechnology, which can produce more food to meet population demands, this is not the case. Why has the production of transgenic foods not had the same acceptance? The debate that has been generated, in conjunction with inconclusive results surrounding the safety of consuming transgenic foods, has been politicized to such an extent that it is difficult for the consumer to be sure how to react to the subject: there are a large number of people who are uncertain and distrustful. Is there a reason for the distrust surrounding the production and consumption of GM foods? The reason may be due to the uncertainty regarding the methods used in their development. GM food may have undesirable properties; transgenic seeds and plants may change the microbial flora of the soil and could contaminate nearby crops (Bagwan et al., 2010), which could, in turn, affect the natural balance. Transferred genes may undesirably contaminate another organism, and organisms with mixed genes could arise between organisms that are evolutionarily distant, such as plants, animals, bacteria and even viruses (Chamas, 2000). 
Ewen and Pustai, scientists in Scotland, showed in 1999 that rats that were fed with GM potatoes developed abnormalities in the gastrointestinal and immune systems. However, they claimed that these problems were not a consequence of the transgenic protein and, rather, that the problems were from the genetic context in which the protein was located.

It has been described that $\mathrm{Bt}$ toxin has immunogenic properties, whose effects have been identified in mice and pigs (Andreassen et al., 2014; Walsh et al., 2011). Pigs fed a GMO diet had a larger uterus and presented severe stomach inflammation compared with pigs fed a comparable non-GMO diet (Carman et al., 2013).

In addition, in another study, rats fed with $\mathrm{Bt}$ aubergine that produces the Cyt1Ac protein presented a significantly increased blood cell count in comparison to the control. Hepatotoxic effects, which included elevated bilirubin and acetylcholinesterase levels, were also detected (Then and Bouer-Panskus, 2017).

In the economic sector, the use of GMOs in Europe has encouraged agricultural biotechnology, which has resulted in more productive agriculture, increasing the incomes of farmers with a minor impact on the environment by reducing pesticide treatments (Gómez-Barbero et al., 2008; Zamora, 2016). In Spain, transgenic Bt corn has saved 193 million euros in corn imports since 1998 (Fundación Antama, 2016). As of 2015, 28 countries have planted 179.7 million ha of biotech crops; 20 of them are developing countries, and 8 of them are industrialized ones. The United State is the largest producer, with 70.8 million ha, and Brazil is the top developing country, having planted 44.2 million ha of biotech crops (Fundación Antama, 2016).

Rural areas with developing economies certainly stand to benefit from crops produced with biotechnology, whether by importing grain or seeds from foreign countries or developing their own
GM crops. Nonetheless, access to the same resources may not be available in countries with growing economies (Delaney, 2015).

\section{Regulation of transgenic food}

The European Food Safety Authority (EFSA) existsin the European Union, which is an institution responsible for ensuring the safety of foods consumed in Europe, including GMOs. One of its roles is to evaluate GMOs and ensure their viability as food for humans.The favorable reception or non-approval of transgenic food is founded on research.Therefore, for all companies applying for the merchandising of their wares in the European Union, a scientific committee must perform a hazard analysis.Any transgenic product must be prejudged by the EFSA before being presented to a European Council decision. Occasionally, the EFSA publishes communications where they explain the lines of work that comply.Those documents make the process transparent and fair.Subsequently, a period is open to submit opinions and propositions that come from companies, universities and diverse associations (EFSA, 2012).

Within the wider European Union legislation on GMOs, the two main legal instruments include the following:

- Directive 2001/18 / EC on the international release into the environment of GMOs.

- Regulated CE no. 1829/2003 on GM food.

On the other hand, the Food and Drug Administration is an organization belonging to the U.S. Department of Health and Human Services in the United States. The primary job of the FDA is to safeguard the safety of U.S. consumers and the effectiveness of marketed drugs, including in particular, the GMOs, both flora and fauna. In 1992, the FDA issued its statement of policy as"food derived from obtaining vegetables, including forms 
that are produced using recombinant DNA" (U.S. Food and Drug Administration, 1992). The FDA has also issued a guidebook for the regulation of genetically engineered animals for the industry, but it could be useful to the consumer where it notes that "It is safe".

In 2010, the FDA allowed the safe consumption of AquAdvantagetransgenic salmon, which was developed in 1989 by AquaBounty Technologies. AquAdvantage salmon includes a gene from the Chinook salmon, which is the largest of the Pacific salmon species, allowing the fish to potentially grow to market size in half the time compared with conventional salmon (Baltá et al., 2013).

\section{Present trends in feeding}

Throughout history, the role of feeding in the lives of humans has transformed. In the beginning, humans only searched for foods to satisfy their biological needs; later, the need was influenced by factors such as luxury, religion, offers and social stratum (García-Urigüen, 2012). Today, there is a certain need to try different foods. The changes in feeding habits are expressed by a transformation in society. The present life pace demands simpler foods. Accordingly, there are gastronomic currents such as "fast food", where food technology plays a very important role in the development of feeding products that are easily and quickly prepared. It is true that technological advancement has led the production of a significant variety of feeding products; however, society demands increasingly harmless foods and foods of higher quality. Consumers are inclined to use organic compounds due to the additional social values that are implied (Gutiérrez-Cedillo et al., 2008). Organic restaurants and gourmet gastronomy have responded to the actual social problems, removing the use of foods prepared with high contents of agrochemicals and the use of transgenic foods. These gastronomic concepts involve utilizing products that are totally organic, in which the ingredients utilized are very selective and of high quality.
Organic foods result from production methods that are considered harmless to the environment (FAO, 2009). The goal of organic farming is to obtain agroecosystems that are socially and ecologically sustainable. The use of organic products can alleviate health problems and,at the same time,promote social justice for the agricultural producers of the region (Gutiérrez-Cedillo et al., 2008).

However, it is necessary to mention that biotechnology helps to protect and preserve the environment by reducing reliance on chemical pesticides and herbicides. Even plants such as poplar trees have been genetically engineered to clean up heavy metal pollution from contaminated soil (Bagwan et al., 2010).

The ecological management of biotechnology attempts to take advantage of this science for the application of a wide range of technologies focused on farming, agro-industry, food industry, livestock, forestry, fishing and aquaculture, with different objectives such as the characterization and conservation of genetic resources for feeding and agriculture, the diagnosis of sickness of plants and animals, the development of vaccines and the production of fermented foods (FAO, 2004; Bagwan et al., 2010; Dash et al., 2016), all without putting aside the environmental considerations. It is necessary to design products and technologies that are useful in diminishing the environmental impact. Using techniques that facilitate an increase in food certainty and practices of sustainable agriculture, biotechnology is expected to be the basis for improvement and strengthening as well as taking advantage of an enriching natural resources.

The main conclusions are as follows. Throughout history, biotechnology has contributed enormously to the advancement of the agriculture and the feeding industry.The use of microorganisms, enzymes and chemical compounds has been implemented in the innovation of feeding resources, offering the public a greater diversity 
of food, in general. Because of biotechnology, there have been achievements in the methods to increase the agricultural production and food supplies for growing population. Biotechnology has created techniques such as the genetic modification, in which it is possible to increase the micronutrient density of food, which is promising for improving the nutritional status and health of poor populations in both rural and urban areas of the developing world.

However, a portion of the world population is still not prepared for the acceptance of genetic manipulation. People still have doubts about the health risks that the consumption of these kinds of food might pose. Therefore, it is necessary to make known the results of the studies and regulations of these products before their commercialization. In addition, it is necessary to demonstrate the economic and social benefits brought about by the genetic manipulation of the feeding resources throughout the developing countries, where these benefits are not very clear.
According to several food scientists, there is an enormous gap in nutritional demand between industrialized and rural areas. Third world countries are still starving for food, despite the phenomenal progress in food production. Therefore, if society in general does not perceive the benefits of genetic manipulation, it is unlikely to be accepted in its entirety.

The present trend indicates a rejection of all types of food that are chemically processed. People are becoming more inclined to consume fresh food. This trend is being observed in some restaurants and even in some homes, and organic orchards are being implemented for the supply of their food resources. In this sense, it is necessary to redirect efforts towards studies that allow sustainable agricultural development, in which the production of high-quality food is environmentally friendly.

Therefore, people cannot ignore biotechnology, as it has an enormous potential of benefits.However, we must proceed responsibly.

\title{
Resumen
}

\begin{abstract}
A. Cano, D. Díaz y C. Morgado. 2017. El papel de la biotecnología en la producción agrícola y en el abastecimiento de alimentos. Cien. Inv. Agr. 44(1): 1-11. En las últimas décadas el desarrollo tecnológico ha ido de la mano con la modernización. Cada día es más evidente el uso de la biotecnología como una herramienta para incrementar la producción de los alimentos. Gracias a los avances en ingeniería genética ha sido posible manipular cultivos y así, poder garantizar el abasto de alimentos entre la población. Sin embargo, estos alimentos no han sido del todo bien recibido por la sociedad, pues todavía existe incertidumbre en torno a sus beneficios tanto a nivel social como a nivel de la salud de los seres humanos. Por otra parte, la modernización agrícola sólo ha favorecido a los países más desarrollados. En países en vías de desarrollo, todavía se observa pobreza, hambre y desnutrición. Por lo tanto, es necesario crear políticas que fomenten la producción y así poder cumplir con la demanda de alimentos que cada día es mayor. En el proceso de la modernización, el desarrollo sustentable ha tomado un gran interés, donde el consumo de alimentos orgánicos ha llegado a convertirse en una prioridad, gracias a que estos alimentos presentan una mayor calidad y que su vez favorecen la producción agrícola regional. En esta revisión se discute el papel que ha tenido la biotecnología en diferentes épocas de la historia para la producción agricola y el desarrollo del sector alimentario.
\end{abstract}

Palabras clave: Agricultura, alimentos orgánicos, alimentos transgénicos, desarrollo, industria alimentaria, nutrición. 


\section{References}

Andreassen M., E. Rocca, T. Bøhn, O.G. Wikmark, J. van den Berg, M. Løvik, T. Traavik, U.C. Nygaard. 2014. Humoral and cellular immune responses in mice after airway administration of Bacillus thuringiensis Cry1Ab and MON810 CrylAb-transgenic maize. Food AgricImmunol 26(4):521-537.

Awais, M., A. Pervez, A. Yaqub, R. Sarwar, F. Alam, and S. Siraj. 2010. Current status of biotechnology in health. American Eurasian J. Agric. \& Environ. Sci 7(2):210-220.

Bagwan, J.D., S.J. Patil, A.S. Mane, V.V. Kadam, and S. Vichare. 2010.Genetically modified crops: Food of the future. Intl. J of Adv Biotech and Research.1(1):21-30.

Baltá Arandes, A., J. Baró Basora, and V. Blanco Saiz. 2013. Alimentos trangenicos:la realidad no siempre supera la ficción. Universidad de Barcelona, España.

Bhupinder, S.S. 2014. Nanotechnology in Agri-food production: an overview. Nanotechnology, Science and Applications. 7:31-53.

Boccia, F., and P. Sarnacchiaro.2015. Genetically modified foods and consumer perspective. Recent Pat Food Nutr Agric. 7:28-34.

Carman, J.A., H.R. Vlieger, L.J. VerSteeg, V.E. Sneller, Robinson Garth W., Clinch-Jones, C.A; Haynes, Julie I; Edwards, John W. 2013. A longterm toxicology study on pigs fed a combined genetically modified (GM) soy and GM maize diet. J OrgSyst 8(1):38-54.

Chamas, A. 2000. Alimentos transgénicos. Invenio3(4-5):149-159.

Dash, A., D.Kundu, M. Das, D. Bose, S. Adak, and R. Banerjee. 2016.Food biotechnology: A step towards improving nutritional quality of food for asian countries. Recent Pat Biotechnol 10:43-57.

Ewen, S.W., and A. Pusztai. 1999. Effects of diets containing genetically modified potatoes expressing Galanthusnivalis lectin on rat small intestine. Lancet 354:1314-1315.

EFSA - European Food Safety Authority. 2011. Scientific opinion on the application (EFSAGMO-BE-2010-79) for the placing on the market of insect resistant genetically modified soybean MON 87701 for food and feed uses, import and processing under Regulation (EC) No 1829/2003 from Monsanto. EFSA Journal 9(7):2309.

EFSA - European Food Safety Authority. 2012.Guidance on the risk assessment of food and feed from genetically modified animals and on animal health and welfare aspects. EFSA Panels on Genetically Modified Organisms (GMO) and Animal Health and Welfare (AHAW). EFSA Journal 10(1):2501.

FAO - Food and Agriculture Organizations of the United Nations. 2000. El Estado Mundial de la Agricultura y la alimentación. La alimentación y agricultura en el mundo: enseñanza de los 50 últimos años. Roma. $329 \mathrm{p}$

FAO - Food and Agriculture Organizations of the United Nations.2004.El Estado Mundial de la Agricultura y la Alimentación. La biotecnología agrícola: ¿una respuesta a la necesidad de los pobres? Roma.227 p.

FAO - Food and Agriculture Organizations of the United Nations.2012. El Estado Mundial de la Agricultura y la Alimentación. Invertir en la agricultura para tener un mejor futuro. Roma, Italia. $179 \mathrm{pp}$.

FAO - Food and Agriculture Organizations of the United Nations.2013. El Estado Mundial de la Agricultura y la Alimentación. Sistemas alimentarios para una mejor nutrición. Roma, Italia. $99 \mathrm{pp}$

Fernández-Suárez, M.R. 2009. Alimentos transgénicos: ¿Qué tan seguro es su consumo? Revista Digital Universitaria 10(4):1-15.

Fundación Antama. 2016. Cultivo de maíz Bt ha permitido a España el ahorro de 193 millones de Euros en importaciones de maíz desde 1998. Fundación Antama. Consultado 25 de noviembre de 2016. Disponible en www.fundación-altama.org.

Fundación Antama. 2016. Infografía: Países en los que se cultivan transgénicos. Fundación Antama. www. fundación-antama.org (accesed 2 Dec. 2016).

García-Urigüen, P. 2012. La alimentación de los mexicanos. Cambios sociales y económicos, y su impacto en los hábitos alimenticios. CANACINTRA.Primera edición. México D.F. 
Gómez-Barbero M., J. Berbel, E. Rodríguez-Cerezo. 2008. Bt corn in Spain - the performance of the EU's first GM crop.NatureBiotechnology 26, $384-386$.

Gutiérrez-Cedillo, J.G., L.I. Aguilera-Gómez, C.E. González-Esquivel. 2008. Agroecología y Sustentabilidad. Convergencia. Revista de Ciencias Sociales 5(46):51-87

Herrera-Díaz, N., J.L. Gómez-Solís. 2011. La biotecnologíay los alimentos transgénicos. Organismos modificados genéticamente (OMG). Synthesis 57:22-24.

Madigan, M., J. Martinko, J. Parker. (editors). 2007. Brock Biología de los microorganismos. México. Pearson.

Mahanty, T., S. Bhattacharjee, M. Goswami, P. Bhattacharyya, B. Das, A. Ghosh, and P. Tribedi. 2016. Biofertilizers: a potential approach for sustainable agriculture development. Environ SciPollut Res Int. 23(21):1-21.

Nakitto, A.M., J.H Muyonga, and D. Nakimbugwe. 2015. Effects of combined traditional processing method on the nutritional quality of beans. Food Sci. Nutr 3(3):233-241.

Overton, M. 1996. Agricultural revolution in England: the transformation of agrarian economy 1500 1850. CambrigeUniversityPress, New York.

PALT - Plataforma Andalucía libre de transgénicos. 2014. Impacto de los cultivos y alimentos trangenicos sobre la salud. Inseguridad, opacidad e irresponsabilidad. Editorial PALT. Sevilla (Andalucia) España.

Persley, G.J. 1991. Beyond Mendel's garden: biotechnology in the service of agriculture. Gran Bretaña. Bookcraft.

Sanahuja, G., R. Banakar, R.M. Twyman, T. Capell, and P. Christou. 2011. Bacillus Thuringiensis: a century of research, development and commercial applications. Plant Biotechnol J 9(3):283-300.
Tabashnik, B.E., F. Huang, M.N. Ghimire, B.R. Leonard, B.D. Siegfried, M.Rangasamy, Y. Yang, Y. Wu, L.J. Gahan, D.G. Heckel, A. Bravo, and M. Soberón. 2011. Efficacy of genetically modified BT toxins against insects with different genetic mechanisms of resistance. Nat Biotechnol 29(12):1128-1131.

Teranishi, R. (editor). 1978. Agricultural and food chemistry past, present, future. EstadosUnidos. Department of agriculture. $\mathrm{p} 65$.

Then, C., and A. Bauer-Panskus. 2017. Possible health impacts of Bt toxins and residues from spraying with complementary herbicides in genetically engineered soybeans and risk assessment as performed by the European Food Safety Authority EFSA. Environ SciEur 29:1-11.

U.S. Food and Drug Administration. 1992. Statement of Policy - Foods Derived from New Plant Varieties. Guidance to Industry for Foods Derived from New Plant Varieties. Department of health and human services. 57. p22984.

Vasey, D.E. 1992. An ecological history of agriculture. Iowa State: University Press. p.28

Walsh, M.C., S.G Buzoianu, G.E. Gardiner, M.C. Rea, E. Gelencser, A., Janosi, M.M. Epstein, R.P. Ross, and Lawlor P.G. 2011. Fate of transgenic DNA from orally administered Bt MON810 maize and effects on immune response and growth in pigs. PLoS ONE 6(11):e27177.

Waters, D.M., A. Mauch, A. Coffey, E.K. Arendt, and E. Zannini. 2015. Lactic Acid Bacteria as a Cell Factory for the Delivery of Functional Biomolecules and Ingredients in Cereal-Based Beverages: A Review. Crit Rev. FoodSciNutr. 55(4) 503-320.

Zamora, A.L. 2016. Los OMG's lograron en 2014 un incremento medio de los ingresos de los agricultores de 90 euros hectárea. Fundación Antama. Consultado el 25 deNoviembre de 2016. Disponible en www.fundación-altama.org 